\title{
Measures of free recall of 900 English nouns: Correlations with imagery, concreteness, meaningfulness, and frequency
}

\author{
JOHN CHRISTIAN, WILLIAM BICKLEY, MICHAEL TARKA, and KEITH CLAYTON \\ Vanderbilt University, Nashville, Tennessee 37240
}

\begin{abstract}
Forty groups of subjects were given six lists of 25 nouns each for immediate free written recall. A measure of free recall was thereby obtained for each of 900 nouns in the Paivio, Yuille, and Madigan (1968) norms, each noun's measure based on the recall of 32 subjects. First-order correlations showed recall to be correlated with imagery, concreteness, meaningfulness, Thorndike-Lorge frequency, and Kučera-Francis frequency. Partial correlations showed meaningfulness to be essentially unrelated to recall and concreteness only moderately related. In contrast to previous comparisons, which were based on smaller ranges of frequency and were more susceptible to list-specific effects, imagery and frequency were found to be approximately equal in their influence on free recall.
\end{abstract}

Presented with this report are measures of free recall for 900 of the 925 English nouns in the Paivio, Yuille, and Madigan (1968) norms. Several considerations led us to obtain these measures. The first was the general issue of which particular attributes of words affect free recall. It is well established in the Paivio et al. data that attributes suspected to influence recall are themselves correlated. Thus, if a relationship between a variable and recall performance is observed, it is important to establish that the effect is not due to contamination by other variables. Considerable effort has been spent along these lines and the influence of rated imagery on free recall seems firmly established (Postman, 1975). However, there are some recent complications with this picture (Richardson 1975a, 1975b), and the roles of rated meaningfuiness and frequency remain ambiguous. A second consideration was the issue of which variable has the greater influence on recall. Since Paivio's (1971) review there has been an increased acceptance of the view that rated imagery is more influential than meaningfulness and frequency. However, in contrast to the weight of evidence implicating the effect of rated imagery on free recall, the claim that imagery is more influential than frequency and meaningfulness is based on very few studies.

Two more immediate concerns compelled the collection of these measures. The first was the outcome of an experiment by Warren (1977), who examined the effect of a pursuit-rotor task on recall by subjects

The authors thank Patti Craig, Rena Dreskin, and Paige Highfield, who not only helped collect data, but also contributed to the research at other stages. We also thank M. Frank Evarts for his help with the unpublished study described in the introduction. Requests for reprints should be sent to Keith Clayton, 134 Wesley Hall, Department of Psychology, Vanderbilt University, Nashville, Tennessee 37240 . engaged in recall and tracking concurrently. In two experiments Warren found that the recall-concurrent task interfered with picture recall but not word recall. This is consistent with the view that a concurrent tracking task interferes with, or suppresses, imagery during recall. If this is so, and if the superior recall of concrete as opposed to abstract nouns is due to the use of imagery during recall, then it follows that the tracking task should differentially interfere with concrete nouns. Warren tested this in a third experiment comparing the recall of nouns that were both high imagery and concrete with the recall of nouns that were both low imagery and abstract but found no differential effect of the concurrent task. High-imagery nouns were recalled better than low-imagery nouns under both tracking and nontracking conditions. This result, and a similar failure by Baddeley, Grant, Wight, and Thomson (1974) to find a differential effect of pursuit-rotor tracking during list presentation on concrete and abstract nouns, serves to question whether it is the image-inducing qualities of high-imagery nouns that are responsible for their ease of recall or whether some other variable is involved. More generally, Postman (1975) has concluded that, "It is far too early to take it for granted that the only important difference between concrete and abstract words is the ease of imaginal encoding" (p. 323). Perhaps the difference is not due to ease of imaginal encoding at all. Richardson (1975a, 1975b) has also recently challenged the usual interpretation that concreteness and imagery tap the same underlying attribute. He simultaneously manipulated concreteness and imagery in a free recall task and found a main effect for concreteness as well as an Imagery by Concreteness interaction. Recall of high-imagery nouns was indistinguishable from recall of low-imagery nouns when concreteness was held constant at a high level. 
The second impetus for the present study became apparent subsequent to an unpublished study of free recall by Clayton and Evarts who simultaneously manipulated rated imagery, meaningfulness, and Thorndike-Lorge (1944) frequency. Sampling the entire range of those variables, the study had two levels of imagery, three levels of meaningfulness, and three levels of frequency. Ninety words were selected from the Paivio, Yuille, and Madigan (1968) norms, five for each of the 18 conditions of the design. The study was designed to assess the joint effects of the stimulus variables on free recall, but the purpose was frustrated by the finding of substantial list-specific effects. That is, both frequency and imagery interacted significantly with lists. Inspection of these interactions showed not simply that the magnitude of the frequency and imagery effects depended on lists, but that the direction of the effects did also. In some lists free recall increased with increased imagery; in others it decreased. The same kind of interaction occurred with frequency. The effects of meaningfulness were similar, except the interaction was marginal. We concluded from these results that in order to avoid list-specific effects we would need an experiment with substantially more words representing each condition. What we came to realize, however, is that the number of words used in the Clayton and Evarts experiment is not atypical of published studies in this area. For example, the significant List by Imagery interaction was based on nine words per cell in our study. Dukes and Bastian (1966) simultaneously manipulated concreteness and frequency with five words per cell. Mueller and Jablonski (Experiment 2, 1970), Paivio, Yuille, and Rogers (Experiment 1, 1969), and Winnick and Kressel (1965) had similar designs with four, six, and four words per cell, respectively. The fact that those investigators got different results probably reflects differences among the particular lists chosen to represent their conditions. On the other hand, the requirement to use a large number of words so as to avoid list-specific effects limits the usefulness of the factorial manipulation of imagery, concreteness, meaningfulness, and frequency. Since the variables are correlated, relatively few words will be found in certain level combinations (e.g., high frequency, high meaningfulness, low imagery). Even starting with the large pool of the Paivio et al. norms, Clayton and Evarts were hard pressed to find five words per condition and also control for other variables. The alternative strategy, of course, is the correlational approach used here.

Two other correlational studies have been reported that have limited usefulness for our purposes. Frincke (1968) obtained free recall measures on 74 nouns and correlated them with measures on 10 other variables including imagery and frequency. One problem with Frincke's data is that no words were included that had a Thorndike-Lorge frequency count less than seven occurrences per million. In addition, four words were excluded from the analyses because more than $20 \%$ of the subjects reported that they had never heard, seen, or used them before. Thus, the frequency variable was severely restricted in Frincke's study. (Examples of norm words with a Thorndike-Lorge count of six or less per million are: ALLIGATOR, BLISTER, PHOTOGRAPH, LECTURER, and BANDIT.) Paivio's (1968) study was based on 30 measures of 96 nouns and, although not as restricted as Frincke's, only 12 words were included which had a Thorndike-Lorge count of six or less per million. It is reasonable that studies attempting to correlate attributes of words should include only those words with which subjects are familiar. However, this restriction limits the range of the frequency manipulation and correspondingly limits the maximum correlation it can achieve with other variables. The Paivio et al. (1968) nouns are more suitable for our purposes since an effort was made by those authors to sample several frequency levels. Of the 925 nouns, 358 are below nine occurrences per million and 26 are at less than one per million.

All of the above developments encouraged the collection of the free recall norms reported here because the norms permit an extensive correlational analysis of the measures currently available on these words. In addition, and perhaps more important, publication of the free recall norms should facilitate future investigations of characteristics of words that influence recall. Thus, for example, if words rated high-imagery are better recalled, but not because of the images they may induce, and if high-imagery words are better recalled, but not because imagery is confounded with meaningfulness and frequency, it follows that some other property correlated with imagery is producing the effect and has yet to be identified. In general, in fact, the availability of norms on the recallability of 900 nouns should simplify at least initial attempts to relate any properties of words to their recallability.

\section{METHOD}

\section{Materials and Procedure}

Decisions on procedural detail were guided by the goal to obtain an average free recall measure of approximately $50 \%$ correct and the desire to minimize contamination by primacy and recency effects. Realizing that the overall level would depend on list length and presentation rate, we took advantage of Murdock's (1962) study and the results of a pilot study to decide on 25 -word lists presented at a 6 -sec rate. Using five words at the beginning and end of each list as buffers against primacy and recency meant 15 positions in each list could be used for the norm words. Although a measure of all 925 nouns in the Paivio et al. norms was desired, 925 does not divide evenly by 15 ; therefore, 900 nouns were randomly chosen with the help of a FORTRAN algorithm. In order to accommodate each group of subjects within a 1-h session, it was decided to give each group six different lists. To obtain a measure on all 900 nouns, 10 different groups were therefore required. Thus, 60 different lists of 15 nouns each were randomly selected and randomly assigned to the 15 nonbuffer positions within the lists. Sixty buffer words, all nouns, were then randomly selected from the 
Thorndike-Lorge (1944) word count, with the restriction that their frequency-count distribution resemble the distribution of norm words. These lists were then presented to a total of 80 subjects. These 80 subjects constitute one replication of the study. In all, four replications were run. In each replication 60 new lists were randomly selected and positioned. The same buffers were used throughout, but randomly assigned to different lists and positions across replications. The final measure of free recall for each word is based on the recall of 32 subjects.

The subjects were read standard free recall instructions (i.e., no mnemonic was suggested and word order was to be ignored). To familiarize the subjects with the procedures, a 15-word practice list was given. These words were randomly selected from the 25 Paivio et al. nouns not used in the experiment proper. Each list was presented via Kodak Carousel projector and followed by $2 \mathrm{~min}$ of written recall. Ten seconds intervened between the recall of one list and presentation of the next. Recall of the last list was followed by $8 \mathrm{~min}$ of unexpected final free recall of all lists. The final free recall measures will not be discussed here.

\section{Subjects}

The subjects were 320 college students. Two-hundred and forty were introductory psychology students at Vanderbilt University participating to partially fulfill a course requirement. The other 80 were general psychology volunteers enrolled at David Lipscomb College.

\section{RESULTS AND DISCUSSION}

The words are presented in the Appendix, together with their recall measures and Kučera-Francis (1967) frequency count. The Kučera-Francis frequency is the number of occurrences in a corpus of $1,014,232$ words. The Thorndike-Lorge frequencies are reported in the original Paivio et al. norms, and the Kucera-Francis measures are included here because they are more recent and because actual frequencies are reported rather than rounded to $\mathrm{A}$ and $\mathrm{AA}$ for high frequencies as they are in the Thorndike-Lorge count. (Examples of words that have changed in frequency between the two counts are MISSILE, 2 to 80 in the more recent count; CONCEPT, 3 to 112 ; APPLE, $A$ to 15 ; and BEAST, $A$ to 9.) The Kučera-Francis scores are positively skewed with mean and mode of 54.7 and 1, respectively, and standard deviation equal to 112.7 . The recall scores are symmetrically distributed around a mean of .40 , standard deviation of .14. The means and standard deviations calculated on the other measures agree with those in Paivio et al. (1968) as they should.

\section{Correlational Analyses}

Reliability. In order to estimate reliability of the recall measure, the following steps were taken. First, the recall score for each replication was calculated for each word. This gave us a 900 by 4 matrix with words as rows and replications as columns. Each word was then treated as "subjects" are treated in standard calculations of reliability, with replications treated as "tests." We then calculated the correlations among the replications, averaged the three correlations between the first and second, first and third, and first and fourth, and inserted this average value into the Spearman-Brown formula. The reliability estimate calculated this way is .57 . When reliability was estimated by analysis of variance in accordance with the suggestion of Winer (1971, pp. 283289 ), the identical value (.57) was found.

First-order correlations. The first-order correlations among the stimulus variables and recall are reported in Table 1. The correlations among imagery, concreteness, meaningfulness, and Thorndike-Lorge frequency are all within .02 of those reported in Paivio et al. (1968). The correlations between the recall measure and each of imagery, concreteness, and meaningfulness agree well with Frincke (1968) and Paivio (1968). All three studies have found recall to be most highly correlated with imagery, next highest with concreteness, and least with meaningfulness. In each case the value obtained here falls between the values reported by Frincke and Paivio.

However, the correlations obtained here between recall and frequency are different from those reported by Frincke and Paivio. In contrast to the correlation of .24 between recall and Thorndike-Lorge frequency, Paivio obtained a value of .01 and Frincke a value of .02 . This difference most likely reflects the difference in the range of frequency values used in these studies. Notice, also, the difference between the way the two frequency counts correlated with imagery and concreteness. Whereas the Thorndike-Lorge frequency count is moderately correlated with imagery and concreteness, the Kučera-Francis count is not related at all.

Multiple and partial correlations. The multiple correlation between recall and the other variables is .47 regardless of which count is used for frequency. Squaring this value shows that with most word attributes known to influence word recall taken into account there

Table 1

First-Order Correlations for Stimulus Variables and Recall

\begin{tabular}{|c|c|c|c|c|c|}
\hline & Imagery & $\begin{array}{l}\text { Concrete- } \\
\text { ness }\end{array}$ & $\begin{array}{l}\text { Meaning- } \\
\text { fulness }\end{array}$ & $\begin{array}{l}\text { Thorndike- } \\
\text { Lorge } \\
\text { Frequency }\end{array}$ & $\begin{array}{l}\text { Kučera- } \\
\text { Francis } \\
\text { Frequency }\end{array}$ \\
\hline Concreteness & .83 & & & & \\
\hline Meaningfulness & .72 & .55 & & & \\
\hline Thorndike-Lorge Frequency & .25 & .13 & .35 & & \\
\hline Kučera-Francis Frequency & .02 & -.04 & .15 & .62 & \\
\hline Recall & .44 & .40 & .31 & .24 & .15 \\
\hline
\end{tabular}


Table 2

Partial Correlations Involving Recall, Imagery, Meaningfulness, Concreteness, and Frequency

\begin{tabular}{ccccc}
\hline Imagery & $\begin{array}{c}\text { Concrete- } \\
\text { ness }\end{array}$ & $\begin{array}{c}\text { Meaning- } \\
\text { fulness }\end{array}$ & $\begin{array}{c}\text { Thorndike- } \\
\text { Lorge } \\
\text { Frequency }\end{array}$ & $\begin{array}{c}\text { Kucera- } \\
\text { Francis } \\
\text { Frequency }\end{array}$ \\
\hline .20 & .07 & -.04 & & .17 \\
.18 & .08 & -.05 & .17 & \\
\hline
\end{tabular}

Note-The entries give the correlation between the variable labeled for the column and the recall measure, with the other variables partialled out. The first row reports partial correlations when the Kucra-Francis frequency count is used, the second when the Thorndike-Lorge count is used.

remains considerable unaccounted for variance. Of course, the multiple correlation is limited by the less than perfect reliability of the recall measure. But that reliability almost certainly is limited in value, because the relative recallability of a given word surely must also depend on the subject who is doing the recalling and the list context into which the word is placed.

The partial correlations are reported in Table 2. Two sets are reported, one with Kucera-Francis used as the frequency count, the other with Thorndike-Lorge used as the frequency count. In each case the partial correlation reported is that between the variable listed in the column heading and free recall, with all other variables partialled out. The conclusions that can be drawn from that data are fairly clear, within the limitations of the correlational approach and given the departures of some of the distributions from normality. When the effects of the other variables are partialled out, the influence of meaningfulness on free recall disappears. This is consistent with Frincke's (1968) correlational study and Paivio and Smythe's (1971) experimental study. Although considerably weakened, concreteness remains mildly associated with recall. This result is consistent with Richardson's (1975a, 1975b) results, but not with Frincke's (1968). Finally, with the other variables controlled, frequency is found to remain positively correlated with free recall and the magnitude of the correlation is similar to the partial correlation of imagery with free recall. This result does not agree with previous findings (Paivio, 1971) but, given the large number of words and the range of frequency used here, the new results seem to be based on firmer evidence.

\section{Analysis of Variance}

The number of norm words correctly recalled by each subject at each serial position within each list was submitted to an analysis of variance. The replication and serial position main effects were significant at the .05 level $[F(3,280)=4.98$ and $F(14,3920)=5.49$, respectively]. The replication effect reflected differences in the two colleges sampled and the serial position effect stemmed from the superior recall at the last three or four nonbuffer positions. Thus, in this study the five buffer words did not absorb all of the recency effect and recency contributed a random source of variance to the recall measures. Efforts were made to adjust individual word recall scores to take into account the position each held throughout the lists, but no effort ever measurably affected the reliability values and the matter was not pursued.

\section{Illustrative Use of the Norms}

One of the uses to which these norms can be put is to investigate the effects of simultaneously manipulating several variables without, or before, performing the actual experiment. An advantage of this procedure is that it allows the use of all words that satisfy each level of variable combinations rather than being restricted to a sample. To illustrate this point, consider an attempt to replicate the interaction reported by Richardson (1975a, 1975b). All words in these norms that correspond to the two levels of concreteness and imagery specified by Richardson's cut-off value were selected. Richardson controlled Thorndike-Lorge frequency by matching, so the words were next dichotomized at a frequency count of 17 occurrences per million. This permitted an examination of the triple interaction between imagery, concreteness, and frequency with no less than 31 words in any of the eight conditions of the design. Means and standard deviations of the free recall scores were then calculated for each condition and are reported in Table 3 . The results are portrayed there in such a way that the influence of imagery on recall can be examined by comparing across columns. Overall, the results do not agree with Richardson (1975a, 1975b), who found that imagery had no effect at high levels of concreteness. Here it is found that imagery has an effect except when frequency is low. Notice, also, that concreteness has a positive effect only when frequency is low. However, when imagery and concreteness are allowed to covary (i.e., high concreteness/high imagery compared with low concreteness/low imagery), as is usually done in studies of imagery, there is an effect of imagery at both levels of frequency. The results also agree with Paivio and

Table 3

Means and Standard Deviations of Free Recall Scores on Words Selected from the Norms to Represent Eight Conditions of the Factorial Manipulation of Imagery, Concreteness, and Frequency

\begin{tabular}{|c|c|c|c|c|c|c|c|}
\hline \multirow[b]{3}{*}{ C } & \multirow[b]{3}{*}{$\mathrm{F}$} & \multicolumn{6}{|c|}{ Imagery } \\
\hline & & \multicolumn{3}{|c|}{ Low } & \multicolumn{3}{|c|}{ High } \\
\hline & & Mean & $\mathrm{SD}$ & $\mathrm{n}$ & Mean & SD & $\mathrm{n}$ \\
\hline Low & $\begin{array}{l}\text { Low } \\
\text { High }\end{array}$ & $\begin{array}{l}.34 \\
.30\end{array}$ & $\begin{array}{l}.11 \\
.13\end{array}$ & $\begin{array}{l}55 \\
57\end{array}$ & $\begin{array}{l}.33 \\
.40\end{array}$ & $\begin{array}{l}.12 \\
.15\end{array}$ & $\begin{array}{l}31 \\
37\end{array}$ \\
\hline High & $\begin{array}{l}\text { Low } \\
\text { High }\end{array}$ & $\begin{array}{l}.36 \\
.27\end{array}$ & $\begin{array}{l}.14 \\
.11\end{array}$ & $\begin{array}{l}35 \\
35\end{array}$ & $\begin{array}{l}.38 \\
.36\end{array}$ & $\begin{array}{l}.13 \\
.13\end{array}$ & $\begin{array}{r}138 \\
92\end{array}$ \\
\hline
\end{tabular}

Note- $C=$ concreteness, $F=$ frequency, and $n$ refers to the number of words that contributed to the mean. 
Smythe's (1971) finding that low-frequency words are recalled better than are high-frequency words when

imagery and concreteness are both held constant at a high level.

\section{APPENDIX}

Listed, in alphabetical order, are the 900 nouns together with each word's Kučera-Francis frequency and free recall measure. The Kučera-Francis frequency is the number of occurrences in a corpus of 1,014,232 words and is the sum of singular and plural forms (except for child and geese). The free recall measure is the proportion of 32 subjects who correctly recalled the word.

\begin{tabular}{|c|c|c|c|c|c|}
\hline NOUN & $\mathrm{K}-\mathrm{F}$ & FR & NOUN & $\mathrm{K}-\mathrm{F}$ & $\mathrm{FR}$ \\
\hline ABBESS & 0 & .438 & AUTOMOBILE & 74 & .375 \\
\hline ABDICATION & 0 & .438 & AVALANCHE & 1 & .594 \\
\hline ABDOMEN & 6 & .500 & AVENUE & 51 & .344 \\
\hline ABDUCTION & 1 & .375 & BABY & 74 & .813 \\
\hline ABERRATION & 8 & .375 & BACKGROUND & 74 & .250 \\
\hline ABILITY & 87 & .375 & BACTERIA & 8 & .438 \\
\hline ABODE & 4 & .313 & BAGPIPE & 1 & .344 \\
\hline ABYSS & 4 & .438 & BANALITY & 0 & .344 \\
\hline ACCORDION & 1 & .375 & BANDIT & 6 & .469 \\
\hline ACROBAT & 1 & .375 & BANKER & 20 & .438 \\
\hline ADAGE & 3 & .313 & BANNER & 10 & .375 \\
\hline ADMIRAL & 1 & .500 & BAR & 122 & .656 \\
\hline ADVANTAGE & 101 & .281 & BARD & 5 & .656 \\
\hline ADVERSITY & 2 & .469 & BARON & 3 & .406 \\
\hline ADVICE & 51 & .313 & BARREL & 32 & .313 \\
\hline AFFECTION & 22 & .281 & BASEMENT & 33 & .500 \\
\hline AFTERLIFE & 0 & .406 & BEAST & 9 & .375 \\
\hline AGILITY & 3 & .281 & BEAVER & 3 & .406 \\
\hline AGONY & 10 & .438 & BEGGAR & 4 & .500 \\
\hline AGREEMENT & 121 & .250 & BELFRY & 1 & .406 \\
\hline AIR & 257 & .625 & BELIEF & 87 & .375 \\
\hline ALCOHOL & 15 & .469 & BELONGINGS & 4 & .219 \\
\hline ALGEBRA & 2 & .406 & BEREAVEMENT & 5 & .469 \\
\hline ALIMONY & 2 & .531 & BETRAYAL & 6 & .344 \\
\hline ALLEGORY & 3 & .219 & BEVERAGE & 9 & .281 \\
\hline ALLIGATOR & 4 & .500 & BIVOUAC & 5 & .813 \\
\hline AMBULANCE & 7 & .500 & BLACKSMITH & 2 & .344 \\
\hline AMOUNT & 216 & .438 & BLANDNESS & 1 & .344 \\
\hline AMOUR & 0 & .500 & BLASPHEMY & 6 & .438 \\
\hline AMPLIFIER & 7 & .313 & BLESSING & 13 & .281 \\
\hline ANECDOTE & 13 & .469 & BLISTER & 5 & .594 \\
\hline ANGER & 48 & .563 & BLOOD & 122 & .531 \\
\hline ANGLE & 62 & .188 & BLOOM & 15 & .594 \\
\hline ANIMAL & 126 & .625 & BLOSSOM & 14 & .625 \\
\hline ANIMOSITY & 3 & .563 & BLUNDERBUSS & 0 & .594 \\
\hline ANKLE & 15 & .563 & BOARD & 286 & .375 \\
\hline ANSWER & 196 & .250 & BODY & 340 & .531 \\
\hline ANTITOXIN & 0 & .531 & BOOK & 289 & .500 \\
\hline ANXIETY & 43 & .438 & BOREDOM & 11 & .594 \\
\hline APPEARANCE & 71 & .156 & BOSOM & 9 & .844 \\
\hline APPLE & 15 & .438 & BOSS & 25 & .563 \\
\hline APPLIANCE & 13 & .219 & BOTTLE & 91 & .406 \\
\hline APTITUDE & 4 & .438 & BOULDER & 13 & .500 \\
\hline ARBITER & 5 & .156 & BOUQUET & 5 & .500 \\
\hline ARM & 215 & .656 & BOWL & 26 & .594 \\
\hline ARMADILLO & 2 & .594 & BOY & 385 & .813 \\
\hline ARMY & 147 & .438 & BRAIN & 63 & .406 \\
\hline ARRAY & 11 & .344 & BRASSIERE & 2 & .688 \\
\hline ARROW & 20 & .313 & BRAVERY & 4 & .313 \\
\hline ARTIST & 112 & .563 & BREAST & 20 & .594 \\
\hline ASSAULT & 19 & .062 & BREEZE & 16 & .406 \\
\hline ATHLETICS & 9 & .438 & BRONZE & 11 & .406 \\
\hline ATMOSPHERE & 84 & .344 & BRUTALITY & 14 & .406 \\
\hline ATROCITY & 2 & .469 & BRUTE & 6 & .438 \\
\hline ATTENDANT & 19 & .438 & BUFFOON & 2 & .594 \\
\hline ATTITUDE & 155 & .188 & BUILDER & 56 & .406 \\
\hline ATTRIBUTE & 18 & .156 & BUILDING & 236 & .563 \\
\hline AUTHOR & 69 & .438 & BULLET & 49 & .688 \\
\hline
\end{tabular}




\begin{tabular}{|c|c|c|}
\hline NOUN & $\mathrm{K} \cdot \mathrm{F}$ & FR \\
\hline BUNGALOW & 1 & .469 \\
\hline BUSYBODY & 0 & .344 \\
\hline BUTCHER & 8 & .250 \\
\hline BUTTER & 27 & .656 \\
\hline BUTTERFLY & 3 & .438 \\
\hline CABIN & 30 & .500 \\
\hline CAMOUFLAGE & 3 & .406 \\
\hline CAMP & 93 & .531 \\
\hline CANDIDATE & 72 & .375 \\
\hline CANDY & 18 & .500 \\
\hline CANE & 12 & .563 \\
\hline CAPACITY & 88 & .094 \\
\hline CAPTIVE & 7 & .281 \\
\hline CAR & 386 & .656 \\
\hline CARAVAN & 10 & .188 \\
\hline CASH & 36 & .375 \\
\hline CAT & 41 & .844 \\
\hline CATERPILLAR & 2 & .469 \\
\hline CATTLE & 97 & .531 \\
\hline CAUSALITY & 0 & .344 \\
\hline CELL & 146 & .594 \\
\hline CELLAR & 27 & .406 \\
\hline CENTENNIAL & 6 & .344 \\
\hline CEREBRUM & 0 & .594 \\
\hline CEREMONY & 32 & .313 \\
\hline CHAIR & 89 & .344 \\
\hline CHANCE & 155 & .281 \\
\hline CHAOS & 17 & .438 \\
\hline CHARLATAN & 1 & .313 \\
\hline CHARM & 28 & .219 \\
\hline CHARTER & 37 & .250 \\
\hline CHASM & 2 & .375 \\
\hline CHIEF & 125 & .375 \\
\hline CHILD & 213 & .531 \\
\hline CHIN & 29 & .500 \\
\hline CHLORIDE & 6 & .281 \\
\hline CHRISTMAS & 27 & .563 \\
\hline CHURCH & 444 & .594 \\
\hline CIGAR & 12 & .469 \\
\hline CIRCLE & 92 & .281 \\
\hline CIRCUIT & 27 & .219 \\
\hline CITATION & 6 & .281 \\
\hline CITY & 500 & .531 \\
\hline CLAW & 4 & .531 \\
\hline CLEANNESS & $\mathbf{0}$ & .344 \\
\hline CLEMENCY & 2 & .344 \\
\hline CLOCK & 28 & .563 \\
\hline COBBLESTONE & 2 & .406 \\
\hline CODE & 57 & .344 \\
\hline COFFEE & 78 & .500 \\
\hline COIN & 19 & .469 \\
\hline COLLEGE & 306 & .656 \\
\hline COLONY & 35 & .406 \\
\hline COMBUSTION & 12 & .344 \\
\hline COMEDY & 41 & .344 \\
\hline COMFORTER & 0 & .406 \\
\hline COMMITTEE & 186 & .406 \\
\hline COMPARISON & 54 & .156 \\
\hline COMPETENCE & 18 & .438 \\
\hline COMPETITION & 63 & .344 \\
\hline COMRADE & 14 & .219 \\
\hline COMRADESHIP & 2 & .406 \\
\hline CONCEPT & 112 & .344 \\
\hline CONFIDENCE & 57 & .219 \\
\hline CONNOISSEUR & 6 & .656 \\
\hline CONQUEST & 11 & .094 \\
\hline CONTENTS & 16 & .156 \\
\hline CONTEXT & 37 & .313 \\
\hline
\end{tabular}

\begin{tabular}{|c|c|c|}
\hline NOUN & $\mathrm{K}-\mathrm{F}$ & FR \\
\hline CONTRACT & 84 & .313 \\
\hline CONTRIBUTION & 66 & .125 \\
\hline CONVENTION & 37 & .406 \\
\hline COOPERATION & 34 & .250 \\
\hline COPYBOOK & 1 & .219 \\
\hline CORD & 8 & .500 \\
\hline CORE & 40 & .188 \\
\hline CORN & 36 & .594 \\
\hline CORNER & 133 & .375 \\
\hline CORPSE & 12 & .625 \\
\hline COST & 405 & .281 \\
\hline COSTUME & 28 & .375 \\
\hline COTTAGE & 25 & .500 \\
\hline COTTON & 38 & .469 \\
\hline COURTSHIP & 2 & .344 \\
\hline COWHIDE & 1 & .531 \\
\hline CRADLE & 8 & .344 \\
\hline CRAG & 2 & .500 \\
\hline CRANIUM & 0 & .563 \\
\hline CREATOR & 16 & .344 \\
\hline CREATURE & 35 & .250 \\
\hline CRIME & 48 & .406 \\
\hline CRISIS & 103 & .219 \\
\hline CRITERION & 22 & .250 \\
\hline CUISINE & 1 & .281 \\
\hline CUSTOM & 32 & .313 \\
\hline DAFFODIL & 1 & .438 \\
\hline DALLIANCE & 0 & .375 \\
\hline DAMSEL & 1 & .531 \\
\hline DAWN & 29 & .406 \\
\hline DAYBREAK & 1 & .219 \\
\hline DAYLIGHT & 16 & .469 \\
\hline DEATH & 285 & .625 \\
\hline DEBACLE & 3 & .375 \\
\hline DECEIT & 2 & .344 \\
\hline DECORATION & 16 & .250 \\
\hline DECREE & 8 & .344 \\
\hline DEDUCTION & 23 & .188 \\
\hline DEED & 16 & .313 \\
\hline DELIRIUM & 3 & .313 \\
\hline DELL & 6 & .469 \\
\hline DELUGE & 4 & .313 \\
\hline DEMOCRACY & 25 & .531 \\
\hline DEMON & 16 & .500 \\
\hline DESTRUCTION & 38 & .469 \\
\hline DETERMINATION & 41 & .313 \\
\hline DETONATION & 3 & .406 \\
\hline DEVELOPMENT & 378 & .344 \\
\hline DEVIL & 27 & .406 \\
\hline DEVOTION & 21 & .406 \\
\hline DIAMOND & 15 & .625 \\
\hline DIRECTION & 164 & .375 \\
\hline DIRT & 43 & .750 \\
\hline DISASTER & 30 & .313 \\
\hline DISCIPLINE & 31 & .188 \\
\hline DISCLOSURE & 6 & .062 \\
\hline DISCONNECTION & 0 & .219 \\
\hline DISCOVERY & 55 & .219 \\
\hline DISCRETION & 14 & .156 \\
\hline DISEASE & 72 & .531 \\
\hline DISPARITY & 3 & .219 \\
\hline DISPOSITION & 14 & .156 \\
\hline DISTINCTION & 56 & .375 \\
\hline DISTRACTION & 4 & .469 \\
\hline DISTURBER & 1 & .281 \\
\hline DOCTOR & 130 & .656 \\
\hline DOLL & 22 & .625 \\
\hline DOLLAR & 143 & .469 \\
\hline
\end{tabular}




\begin{tabular}{|c|c|c|c|c|c|}
\hline NOUN & $\mathrm{K}-\mathrm{F}$ & FR & NOUN & $K-F$ & FR \\
\hline DOMICILE & 1 & .344 & FLAG & 21 & .219 \\
\hline DOOR & 348 & .469 & FLESH & 52 & .563 \\
\hline DOORMAN & 7 & .781 & FLEXIBILITY & 16 & .281 \\
\hline DOVE & 5 & .656 & FLOOD & 25 & .563 \\
\hline DRAMA & 49 & .188 & FLOWER & 80 & .438 \\
\hline DREAM & 94 & .375 & FOAM & 59 & .313 \\
\hline DREAMER & 2 & .500 & FOIBLE & 3 & .563 \\
\hline DRESS & 77 & .563 & FOLLY & 12 & .313 \\
\hline DUMMY & 4 & .313 & FOOTWEAR & 1 & .563 \\
\hline DUST & 71 & .500 & FOREHEAD & 18 & .406 \\
\hline DUTY & 95 & .250 & FOREST & 88 & .531 \\
\hline DWELLER & 4 & .344 & FORETHOUGHT & 1 & .313 \\
\hline DYNASTY & 6 & .313 & FORK & 21 & .469 \\
\hline EARTH & 150 & .438 & FORM & 498 & .344 \\
\hline ECCENTRICITY & 5 & .594 & FORMATION & 44 & .125 \\
\hline ECONOMY & 86 & .375 & FORTUNE & 31 & .438 \\
\hline EDIFICE & 3 & .375 & FOWL & 1 & .469 \\
\hline EDITION & 47 & .219 & FOX & 13 & .656 \\
\hline EFFORT & 272 & .281 & FRANCHISE & 6 & .281 \\
\hline EGO & 13 & .375 & FREEDOM & 131 & .313 \\
\hline ELABORATION & 2 & .219 & FRICTION & 18 & .281 \\
\hline ELBOW & 17 & .563 & FRIEND & 295 & .656 \\
\hline ELEPHANT & 17 & .625 & FROG & 2 & .688 \\
\hline EMANCIPATION & 14 & .594 & FRONTAGE & 7 & .250 \\
\hline EMBEZZLEMENT & 1 & .625 & FUN & 44 & .656 \\
\hline EMERGENCY & 46 & .219 & FUNCTIONARY & 2 & .050 \\
\hline EMPORIUM & 0 & .406 & FUR & 18 & .344 \\
\hline ENCEPHALON & 0 & .375 & FURNITURE & $\begin{array}{l}10 \\
39\end{array}$ & $\begin{array}{l}.344 \\
.500\end{array}$ \\
\hline ENCORE & 1 & .188 & GADFLY & 3 & .563 \\
\hline ENGAGEMENT & 30 & .500 & GAIETY & 12 & .006 \\
\hline ENGINE & 67 & .469 & GALAXY & 10 & $\begin{array}{l}.400 \\
.438\end{array}$ \\
\hline ENSEMBLE & 14 & .219 & GALLERY & 32 & .344 \\
\hline ENTERPRISE & 45 & .438 & GARDEN & 92 & .531 \\
\hline EPISODE & 18 & .188 & GARMENTS & 12 & .281 \\
\hline EPISTLE & 1 & .281 & GARRET & 0 & .563 \\
\hline EQUITY & 7 & .469 & GEESE & 3 & .406 \\
\hline ERRAND & 7 & .250 & GEM & 6 & .406 \\
\hline EVANGELIST & 2 & .625 & GENDER & 3 & .281 \\
\hline EVENT & 182 & .313 & GENIUS & 24 & .344 \\
\hline EVIDENCE & 209 & .156 & GHOST & 16 & .531 \\
\hline EXACTITUDE & 0 & .281 & GIFT & 44 & .469 \\
\hline EXAMINATION & 37 & .344 & GILT & 3 & .375 \\
\hline EXCLUSION & 8 & .313 & GINGHAM & 3 & .281 \\
\hline EXCUSE & 29 & .188 & GIRL & 362 & .844 \\
\hline EXERTION & 2 & .219 & GIST & 1 & .469 \\
\hline EXHAUST & 8 & .344 & GLACIER & 2 & .500 \\
\hline EXHAUSTION & 1 & .250 & GLORY & 25 & .250 \\
\hline EXPLANATION & 58 & .344 & GLUTTON & 3 & .406 \\
\hline EXPRESSION & 94 & .219 & GOBLET & 0 & .344 \\
\hline EXTERMINATION & 1 & .594 & GODDESS & 3 & .563 \\
\hline FABRIC & 44 & .406 & GOLD & 52 & .594 \\
\hline FACILITY & 110 & .281 & GOLF & 34 & .469 \\
\hline FACT & 534 & .438 & GORE & 7 & .438 \\
\hline FACTORY & 56 & .375 & GRADUATION & 11 & .438 \\
\hline FALCONER & 0 & .313 & GRANDMOTHER & 10 & .781 \\
\hline FALLACY & 1 & .281 & GRASS & 54 & .438 \\
\hline FANTASY & 18 & .281 & GRAVITY & 7 & .250 \\
\hline FATE & 36 & .375 & GREED & 3 & .281 \\
\hline FATIGUE & 13 & .438 & GREEN & 121 & .750 \\
\hline FAULT & 29 & .188 & GRIEF & 10 & .188 \\
\hline FELINE & 2 & .563 & GUARDHOUSE & 1 & .594 \\
\hline FESTIVITY & 8 & .188 & GYMNASTICS & 11 & .656 \\
\hline FEUDALISM & 1 & $\begin{array}{l}.100 \\
.438\end{array}$ & HABITATION & 0 & .469 \\
\hline FIGMENT & 2 & .188 & HAIRPIN & 1 & .281 \\
\hline FIORD & 2 & .500 & HALL & 156 & .531 \\
\hline FIRE & 204 & .313 & HAMLET & 7 & .406 \\
\hline FIREPLACE & 7 & .406 & HAMMER & 9 & .438 \\
\hline FIRMAMENT & 0 & .500 & HANKERING & 0 & .219 \\
\hline FISHERMAN & 12 & .563 & HAPPINESS & 23 & .594 \\
\hline
\end{tabular}




\begin{tabular}{|c|c|c|c|c|c|}
\hline NOUN & $\mathrm{K}-\mathrm{F}$ & FR & NOUN & $\mathrm{K}-\mathrm{F}$ & FR \\
\hline HARDSHIP & 14 & .156 & INTELLECT & 5 & .375 \\
\hline HARDWOOD & 1 & .406 & INTEREST & 413 & .281 \\
\hline HARNESS & 10 & .344 & INTERIM & 11 & .375 \\
\hline HARP & 1 & .281 & INTERVIEW & 52 & .438 \\
\hline HATRED & 20 & .313 & INTIMATE & 21 & .438 \\
\hline HEADLIGHT & 8 & .438 & INVESTIGATION & 73 & .438 \\
\hline HEADQUARTERS & 65 & .469 & INVOICE & 1 & .313 \\
\hline HEALTH & 105 & .375 & IRON & 50 & .469 \\
\hline HEARING & 84 & .156 & IRONY & 13 & .188 \\
\hline HEAVEN & 52 & .656 & ISLANDER & 6 & .375 \\
\hline HENCHMAN & 3 & .406 & ITEM & 126 & .344 \\
\hline HEREDITY & 3 & .250 & JAIL & 24 & .688 \\
\hline HEROISM & 3 & .156 & JEALOUSY & 5 & .438 \\
\hline HIDE & 27 & .406 & JELLY & 4 & .406 \\
\hline HIERARCHY & 10 & .438 & JEOPARDY & 4 & .094 \\
\hline HILLSIDE & 9 & .656 & JOKE & 31 & .406 \\
\hline HINDRANCE & 2 & .250 & JOURNAL & 47 & .219 \\
\hline HINT & 19 & .219 & JOY & 47 & .656 \\
\hline HISTORY & 297 & .438 & JUDGE & 97 & .531 \\
\hline HOME & 609 & .656 & JUGGLER & 0 & .344 \\
\hline HOMICIDE & 6 & .344 & JURY & 68 & .531 \\
\hline HONEYCOMB & 0 & .281 & JUSTICE & 117 & .438 \\
\hline HONOR & 81 & .500 & KEG & 3 & .563 \\
\hline HOOF & 9 & .469 & KERCHIEF & 1 & .344 \\
\hline HOPE & 226 & .469 & KEROSENE & 6 & .375 \\
\hline HORSE & 185 & .563 & KETTLE & 3 & .438 \\
\hline HORSEHAIR & 1 & .563 & KINDNESS & 6 & .344 \\
\hline HOSPITAL & 130 & .594 & KINE & 0 & .500 \\
\hline HOSTAGE & 5 & .281 & KING & 95 & .531 \\
\hline HOSTILITY & 11 & .281 & KISS & 21 & .563 \\
\hline HOTEL & 146 & .438 & KNOWLEDGE & 145 & .250 \\
\hline HOUND & 10 & .438 & LABYRINTH & 1 & .438 \\
\hline HOUR & 319 & .500 & LAD & 7 & .688 \\
\hline HOUSE & 674 & .625 & LAKE & 62 & .750 \\
\hline HUMOR & 47 & .313 & LANDSCAPE & 25 & .438 \\
\hline HURDLE & 4 & .313 & LARK & 4 & .375 \\
\hline HURRICANE & 8 & .219 & LAW & 387 & .719 \\
\hline HYPOTHESIS & 22 & .406 & LAWN & 20 & .469 \\
\hline ICEBOX & 3 & .500 & LEAFLET & 4 & .313 \\
\hline IDEA & 338 & .313 & LECTURE & 31 & .406 \\
\hline IDIOM & 10 & .281 & LECTURER & 6 & .375 \\
\hline IGNORANCE & 16 & .281 & LEGGINGS & 1 & .469 \\
\hline ILLUSION & 44 & .375 & LEGISLATION & 46 & .281 \\
\hline IMMUNITY & 7 & .375 & LEMON & 19 & .563 \\
\hline IMPACT & 70 & .156 & LEMONADE & 3 & .375 \\
\hline IMPOTENCY & 1 & .250 & LENGTH & 139 & .125 \\
\hline IMPROPRIETY & 1 & .188 & LEOPARD & 1 & .500 \\
\hline IMPULSE & 32 & .219 & LETTER & 260 & .625 \\
\hline INANITY & 0 & .313 & LETTERHEAD & 1 & .469 \\
\hline INCIDENT & 50 & .156 & LIBRARY & 90 & .344 \\
\hline INCLEMENCY & 0 & .313 & LICE & 2 & .344 \\
\hline INCREMENT & 0 & .375 & LIFE & 715 & .406 \\
\hline INDUCEMENT & 3 & .406 & LIMB & 10 & .469 \\
\hline INDUSTRY & 207 & .375 & LIME & 13 & .656 \\
\hline INEBRIETY & 0 & .344 & LIMELIGHT & 1 & .250 \\
\hline INFANT & 14 & .344 & LINK & 23 & .250 \\
\hline INFECTION & 13 & .469 & LIP & 87 & .656 \\
\hline INFIRMARY & 1 & .594 & LOBSTER & 1 & .500 \\
\hline INGRATITUDE & 1 & .438 & LOCKER & 9 & .438 \\
\hline INHABITANT & 13 & .219 & LOQUACITY & 1 & .375 \\
\hline INJUR Y & 38 & .469 & LORD & 96 & .750 \\
\hline INK & 8 & .375 & LOVE & 251 & .625 \\
\hline INN & 10 & .688 & LOYALTY & 25 & .250 \\
\hline INSECT & 37 & .500 & LUBRICANT & 2 & .406 \\
\hline INSOLENCE & 6 & .313 & LUMP & 10 & .313 \\
\hline INSTANCE & 112 & .188 & MACARONI & 0 & .406 \\
\hline INSTITUTE & 51 & .281 & MACHINE & 157 & .313 \\
\hline INSTRUCTOR & 9 & .563 & MADNESS & 2 & .313 \\
\hline INSTRUMENT & 73 & .219 & MAGAZINE & 64 & .250 \\
\hline
\end{tabular}




\begin{tabular}{|c|c|c|}
\hline NOUN & $\mathrm{K} \cdot \mathrm{F}$ & FR \\
\hline MAGNITUDE & 30 & .250 \\
\hline MAIDEN & 4 & .344 \\
\hline MAJORITY & 60 & .188 \\
\hline MAKER & 31 & .375 \\
\hline MALADY & 3 & .438 \\
\hline MALARIA & 3 & .406 \\
\hline MALICE & 2 & .281 \\
\hline MAMMAL & 4 & .219 \\
\hline MANAGEMENT & 93 & .531 \\
\hline MANTLE & 48 & .406 \\
\hline MARKET & 186 & .469 \\
\hline MARRLAGE & 122 & .500 \\
\hline MAST & 8 & .344 \\
\hline MASTER & 96 & .500 \\
\hline MASTERY & 10 & .219 \\
\hline MATERIAL & 271 & .344 \\
\hline MATHEMATICS & 20 & .469 \\
\hline MEADOW & 24 & .375 \\
\hline MEAT & 57 & .500 \\
\hline MEDALLION & 1 & .344 \\
\hline MEETING & 187 & .250 \\
\hline MEMORY & 91 & .656 \\
\hline MENACE & 9 & .188 \\
\hline MERCY & 20 & .375 \\
\hline METAL & 68 & .469 \\
\hline METHOD & 284 & .469 \\
\hline METROPOLIS & 8 & .219 \\
\hline MICROSCOPE & 9 & .375 \\
\hline MILEAGE & 15 & .344 \\
\hline MIND & 381 & .563 \\
\hline MIRACLE & 24 & .188 \\
\hline MIRAGE & 0 & .250 \\
\hline MISCHIEF & 5 & .313 \\
\hline MISCONCEPTION & 6 & .531 \\
\hline MISERY & 17 & .469 \\
\hline MISSILE & 80 & .469 \\
\hline MOLECULE & 14 & .313 \\
\hline MOMENT & 296 & .250 \\
\hline MONARCH & 3 & .500 \\
\hline MONEY & 267 & .563 \\
\hline MONK & 26 & .500 \\
\hline MONTH & 319 & .250 \\
\hline MOOD & 45 & .281 \\
\hline MORAL & 149 & .406 \\
\hline MORGUE & 1 & .500 \\
\hline MOSQUITO & 2 & .438 \\
\hline MOSS & 9 & .531 \\
\hline MOTHER & 241 & .813 \\
\hline MOUNTAIN & 76 & .563 \\
\hline MUCUS & 2 & .500 \\
\hline MULE & 7 & .406 \\
\hline MULTIPLICATION & 6 & .438 \\
\hline MURDER & 87 & .438 \\
\hline MUSICIAN & 64 & .469 \\
\hline NAIL & 20 & .313 \\
\hline NAMESAKE & 2 & .344 \\
\hline NECESSITY & 53 & .188 \\
\hline NECTAR & 3 & .344 \\
\hline NEPHEW & 14 & .563 \\
\hline NEWSPAPER & 103 & .469 \\
\hline NIGHTFALL & 4 & .438 \\
\hline NONSENSE & 13 & .125 \\
\hline NOOSE & 3 & .469 \\
\hline NORTHWEST & 25 & .406 \\
\hline NUN & 6 & .563 \\
\hline NURSERY & 1 & .344 \\
\hline NUTMEG & 4 & .281 \\
\hline NYMPH & 2 & .438 \\
\hline OATS & 7 & .531 \\
\hline
\end{tabular}

\begin{tabular}{|c|c|c|}
\hline NOUN & $\mathrm{K}-\mathrm{F}$ & FR \\
\hline OBEDIENCE & 10 &.$\overline{313}$ \\
\hline OBSESSION & 6 & .219 \\
\hline OCCASION & 80 & .219 \\
\hline OCEAN & 37 & .406 \\
\hline ODOR & 22 & .438 \\
\hline OFFICER & 184 & .469 \\
\hline OFFSHOOT & 0 & .344 \\
\hline ONSLAUGHT & 6 & .313 \\
\hline OPINION & 140 & .281 \\
\hline OPIUM & 16 & .563 \\
\hline ORCHESTRA & 64 & .344 \\
\hline ORIGIN & 51 & .156 \\
\hline ORIGINATOR & 0 & .281 \\
\hline OSCULATION & 0 & .344 \\
\hline OUTCOME & 37 & .313 \\
\hline OUTSIDER & 11 & .250 \\
\hline OVEN & 8 & .313 \\
\hline OWNER & 68 & .500 \\
\hline OWNERSHIP & 25 & .313 \\
\hline OXYGEN & 46 & .313 \\
\hline PACIFISM & 3 & .188 \\
\hline PACT & 5 & .531 \\
\hline PAINTER & 34 & .375 \\
\hline PALACE & 43 & .281 \\
\hline PANIC & 22 & .250 \\
\hline PANORAMA & 5 & .531 \\
\hline PARTY & 208 & .406 \\
\hline PARITY & 275 & .375 \\
\hline PASSAGEWAY & 4 & .344 \\
\hline PASSION & 40 & .406 \\
\hline PATENT & 54 & .188 \\
\hline PEACEMAKER & 0 & .406 \\
\hline PEACH & 4 & .594 \\
\hline PELT & 9 & .469 \\
\hline PENCIL & 38 & .469 \\
\hline PEP & 0 & .438 \\
\hline PEPPER & 13 & .406 \\
\hline PERCEPTION & 38 & .281 \\
\hline PERFORMER & 20 & .344 \\
\hline PERIODICAL & 9 & .313 \\
\hline PERJURY & 3 & .531 \\
\hline PERMISSION & 27 & .219 \\
\hline PERSON & 296 & .656 \\
\hline PHANTOM & 2 & .250 \\
\hline PHOTOGRAPH & 34 & .156 \\
\hline PHYSICIAN & 20 & .469 \\
\hline PIANIST & 17 & .438 \\
\hline PIANO & 39 & .406 \\
\hline PICTURE & 230 & .344 \\
\hline PIPE & 27 & .406 \\
\hline PISTON & 10 & .375 \\
\hline PLAIN & 62 & .344 \\
\hline PLANK & 12 & .438 \\
\hline PLANT & 184 & .375 \\
\hline PLEASURE & 68 & .375 \\
\hline PLEDGE & 6 & .219 \\
\hline POET & 131 & .375 \\
\hline POETRY & 88 & .250 \\
\hline POLE & 30 & .438 \\
\hline POLICEMAN & 34 & .563 \\
\hline POLLUTION & 6 & .313 \\
\hline PORTAL & 3 & .281 \\
\hline PORTRAIT & 24 & .281 \\
\hline POSITION & 295 & .094 \\
\hline POSTER & 8 & .344 \\
\hline POTATO & 30 & .375 \\
\hline POVERTY & 20 & .156 \\
\hline POWER & 415 & .406 \\
\hline PRAIRIE & 21 & .438 \\
\hline
\end{tabular}




\begin{tabular}{|c|c|c|}
\hline NOUN & $\mathrm{K}-\mathrm{F}$ & FR \\
\hline PRAYER & 40 & .531 \\
\hline PRESENT & 410 & .188 \\
\hline PRESSURE & 223 & .438 \\
\hline PRESTIGE & 29 & .188 \\
\hline PREVIEW & 1 & .250 \\
\hline PRIEST & 32 & .781 \\
\hline PRISON & 45 & .594 \\
\hline PRISONER & 28 & .625 \\
\hline PROCESSION & 5 & .344 \\
\hline PRODUCT & 195 & .219 \\
\hline PROFESSION & 42 & .500 \\
\hline PROFESSOR & 73 & .625 \\
\hline PROFILE & 18 & .188 \\
\hline PROMOTION & 26 & .125 \\
\hline PROPERTY & 222 & .313 \\
\hline PROPRIETOR & 16 & .281 \\
\hline PROSECUTOR & 10 & .531 \\
\hline PROSPERITY & 14 & .219 \\
\hline PROXY & 7 & .344 \\
\hline PUDDING & 1 & .563 \\
\hline PUPIL & 45 & .375 \\
\hline PYTHON & 14 & .438 \\
\hline QUALITY & 159 & .219 \\
\hline QUANTITY & 44 & .313 \\
\hline QUEEN & 51 & .344 \\
\hline QUEST & 16 & .219 \\
\hline RAILROAD & 74 & .313 \\
\hline RATING & 19 & .094 \\
\hline RATTLE & 6 & .344 \\
\hline REACTION & 166 & .250 \\
\hline RECITAL & 11 & .313 \\
\hline RECOGNITION & 44 & .500 \\
\hline REFLECTION & 39 & .344 \\
\hline REFLEX & 10 & .219 \\
\hline REFRIGERATOR & 25 & .656 \\
\hline REMINDER & 10 & .219 \\
\hline RENDEZVOUS & 7 & .375 \\
\hline REPLACEMENT & 23 & .188 \\
\hline REPTILE & 0 & .469 \\
\hline RESEARCH & 172 & .500 \\
\hline RESIDUE & 11 & .406 \\
\hline RESTAURANT & 53 & .594 \\
\hline RETAILER & 6 & .469 \\
\hline REVOLT & 10 & .250 \\
\hline REVOLVER & 14 & .344 \\
\hline RHAPSODY & 0 & .469 \\
\hline RHEUMATISM & 3 & .375 \\
\hline RITUAL & 29 & .281 \\
\hline RIVER & 182 & .594 \\
\hline ROBBER & 8 & .594 \\
\hline ROBBERY & 13 & .281 \\
\hline ROCK & 98 & .563 \\
\hline ROD & 22 & .469 \\
\hline ROSIN & 0 & .344 \\
\hline RUBBLE & 1 & .313 \\
\hline SADNESS & 6 & .313 \\
\hline SAFETY & 48 & .219 \\
\hline SALAD & 12 & .344 \\
\hline SALARY & 51 & .188 \\
\hline SALOON & 20 & .406 \\
\hline SALUTATION & 1 & .188 \\
\hline SALUTE & 3 & .344 \\
\hline SATIRE & 12 & .250 \\
\hline SAUCE & 25 & .406 \\
\hline SAVANT & 0 & .344 \\
\hline SCARLET & 3 & .375 \\
\hline SCIENCE & 166 & .594 \\
\hline SCORPION & 0 & .313 \\
\hline & 105 & .688 \\
\hline
\end{tabular}

\begin{tabular}{|c|c|c|}
\hline NOUN & $\mathrm{K} \cdot \mathrm{F}$ & FR \\
\hline SEASON & 122 & .281 \\
\hline SEAT & 69 & .469 \\
\hline SENSATION & 24 & .375 \\
\hline SENTIMENT & 10 & .250 \\
\hline SERF & 1 & .531 \\
\hline SERIES & 130 & .281 \\
\hline SESSION & 106 & .406 \\
\hline SETTLEMENT & 32 & .344 \\
\hline SETTLER & 15 & .156 \\
\hline SHADOW & 56 & .375 \\
\hline SHAME & 22 & .250 \\
\hline SHEEPSKIN & 3 & .250 \\
\hline SHIP & 126 & .594 \\
\hline SHOCK & 36 & .406 \\
\hline SHORE & 70 & .469 \\
\hline SHOTGUN & 9 & .531 \\
\hline SHRIEK & 5 & .406 \\
\hline SICKNESS & 6 & .469 \\
\hline SILENCE & 55 & .406 \\
\hline SIMILE & 1 & .250 \\
\hline SITUATION & 247 & .062 \\
\hline SKILLET & 2 & .500 \\
\hline SKIN & 54 & .563 \\
\hline SKULL & 5 & .406 \\
\hline SKY & 70 & .656 \\
\hline SLAVE & 74 & .625 \\
\hline SLIPPER & 10 & .531 \\
\hline SLUSH & 0 & .469 \\
\hline SNAKE & 70 & $.50 \mathrm{C}$ \\
\hline SOBRIETY & 1 & .563 \\
\hline SOCIALIST & 21 & .344 \\
\hline SOIL & 69 & .375 \\
\hline SONATA & 15 & .469 \\
\hline SOUL & 69 & .531 \\
\hline SOVEREIGN & 33 & .375 \\
\hline SPEAKEASY & 1 & .625 \\
\hline SPEAKER & 63 & .313 \\
\hline SPEECH & 82 & .438 \\
\hline SPIRE & 8 & .281 \\
\hline SPIRIT & 226 & .250 \\
\hline SPRAY & 17 & .188 \\
\hline SPREE & 4 & .125 \\
\hline SQUARE & 156 & .375 \\
\hline STAGECOACH & 3 & .281 \\
\hline STAIN & 16 & .438 \\
\hline STAR & 54 & .281 \\
\hline STEAM & 17 & .375 \\
\hline STEAMER & 1 & .281 \\
\hline STEERAGE & 0 & .188 \\
\hline STONE & 70 & .531 \\
\hline STOREROOM & 1 & .438 \\
\hline STORM & 32 & .188 \\
\hline STRAWBERRY & 2 & .594 \\
\hline STREET & 304 & .375 \\
\hline STRENGTH & 140 & .406 \\
\hline STRING & 35 & .344 \\
\hline STUB & 5 & .438 \\
\hline STUDENT & 344 & .688 \\
\hline STYLE & 118 & .156 \\
\hline SUBSTITUTE & 27 & .125 \\
\hline SUBTRACTION & 6 & .156 \\
\hline SUDS & 9 & .438 \\
\hline SUGAR & 34 & .313 \\
\hline SULPHUR & 3 & .188 \\
\hline SULTAN & 7 & .563 \\
\hline SUNBURN & 5 & .281 \\
\hline SUNSET & 14 & $.50 C$ \\
\hline SUPPLICATION & 0 & .281 \\
\hline SUPPRESSION & 7 & .215 \\
\hline
\end{tabular}




\begin{tabular}{|c|c|c|}
\hline NOUN & $\mathrm{K}-\mathrm{F}$ & FR \\
\hline$\overline{\text { SURTAX }}$ & 0 & .406 \\
\hline SWAMP & 7 & .531 \\
\hline TABLE & 242 & .313 \\
\hline TABLESPOON & 13 & .375 \\
\hline TANK & 30 & .438 \\
\hline TEACHER & 149 & .688 \\
\hline TEMERITY & 1 & .344 \\
\hline TEMPEST & 2 & .219 \\
\hline TEMPLE & 42 & .594 \\
\hline TENDENCY & 54 & .125 \\
\hline THEOLOGIAN & 14 & .500 \\
\hline THEORY & 149 & .250 \\
\hline THICKET & 3 & .438 \\
\hline THIEF & 17 & .250 \\
\hline THISTLEDOWN & 0 & .469 \\
\hline THORN & 4 & .438 \\
\hline THOUGHT & 569 & .375 \\
\hline TICKET & 30 & .438 \\
\hline TIDBIT & 3 & .250 \\
\hline TIME & 1899 & .531 \\
\hline TIMEPIECE & 1 & .281 \\
\hline TOAST & 19 & .281 \\
\hline TOBACCO & 19 & .250 \\
\hline TOMAHAWK & 0 & .438 \\
\hline TOMB & 13 & .406 \\
\hline TOOL & 74 & .500 \\
\hline TOWER & 18 & .531 \\
\hline TOY & 15 & .594 \\
\hline TRACTION & 0 & .281 \\
\hline TRAGEDY & 56 & .156 \\
\hline TREE & 160 & .531 \\
\hline TRELLIS & 1 & .406 \\
\hline TRIBUTE & 25 & .281 \\
\hline TRIPOD & 4 & .344 \\
\hline TROOPS & 69 & .594 \\
\hline TROUBLE & 156 & .250 \\
\hline TRUCE & 5 & .219 \\
\hline TRUCK & 79 & .563 \\
\hline TRUMPET & 7 & .250 \\
\hline TRUTH & 130 & .438 \\
\hline TWEEZERS & 0 & .469 \\
\hline TWILIGHT & 4 & .250 \\
\hline TYPHOON & 1 & .281 \\
\hline UMBRELLA & 11 & .281 \\
\hline UNBELIEVER & 0 & .250 \\
\hline UNDERWORLD & 6 & .500 \\
\hline UNIFICATION & 10 & .313 \\
\hline UNIT & 190 & .375 \\
\hline UNIVERSITY & 246 & .719 \\
\hline UNREALITY & 2 & .188 \\
\hline UPKEEP & 6 & .281 \\
\hline UTENSIL & 3 & .469 \\
\hline VACCINATION & 2 & .219 \\
\hline VACUUM & 20 & .313 \\
\hline VALLEY & 78 & .375 \\
\hline VANITY & 8 & .344 \\
\hline VAPOR & 12 & .219 \\
\hline VEGETABLE & 26 & .563 \\
\hline VEHICLE & 88 & .313 \\
\hline VELOCITY & 32 & .500 \\
\hline VENOM & 2 & .500 \\
\hline VESSEL & 28 & .250 \\
\hline VEST & 5 & .406 \\
\hline VESTIBULE & 2 & .406 \\
\hline VICTIM & 46 & .469 \\
\hline VICTORY & 68 & .406 \\
\hline VIGILANCE & 4 & .313 \\
\hline VIGOR & 14 & .375 \\
\hline
\end{tabular}

\begin{tabular}{lrl}
\hline NOUN & K-F & FR \\
\hline VILLAGE & 84 & .469 \\
VIOLATION & 20 & .156 \\
VIRTUE & 45 & .344 \\
VISION & 63 & .344 \\
VOCATION & 3 & .219 \\
VOLCANO & 3 & .438 \\
VOLUME & 179 & .438 \\
WARBLER & 0 & .406 \\
WARMTH & 28 & .469 \\
WATER & 484 & .500 \\
WEAPON & 103 & .406 \\
WELFARE & 53 & .406 \\
WENCH & 0 & .563 \\
WHALE & 0 & .469 \\
WHALEBONE & 0 & .375 \\
WHEAT & 9 & .469 \\
WHOLESALER & 1 & .250 \\
WIFE & 249 & .781 \\
WIGWAM & 0 & .406 \\
WINDOW & 172 & .469 \\
WINE & 96 & .531 \\
WINTER & 85 & .406 \\
WISTFULNESS & 0 & .438 \\
WOMAN & 419 & .781 \\
WOODS & 25 & .500 \\
WORKHOUSE & 0 & .406 \\
WORLD & 794 & .469 \\
YACHT & 7 & .469
\end{tabular}

\section{REFERENCES}

Baddeley, A. D., Grant, S., Wight, E., \& Thomson, N. Imagery and visual working memory. In P. M. Rabbitt \& S. Dornic (Eds.), Attention and performance (Vol. 5). New York: Academic Press, 1974.

DUKEs. W. F., \& Bastian, J. Recall of abstract and concrete words equated for meaningfulness. Journal of Verbal Learning and Verbal Behavior, 1966, 5, 455-458.

Frincke, G. Word characteristics, associative-relatedness, and the free recall of nouns. Joumal of Verbal Learning and Verbal Behavior, 1968, 7, 366-372.

KuČERA, N., \& Francis, W. N. Computational analysis of present-day American English. Providence, R.I: Brown University Press, 1967.

Mueller, J. H., \& Jablonski, E. M. Instructions, noun imagery, and priority in free recall. Psychological Reports, 1970, 27. 559-566.

Murpock, B. B., JR. The serial position effect of free recall. Journal of Experimental Psychology, 1962, 64. 482-488.

Paivio, A. A factor-analytic study of word attributes and verbal learning. Joumal of Verbal Leaming and Verbal Behavior, 1968, 7, 41-49.

Paivio, A. Imagery and verbal processes. New York: Holt. Rinehart, \& Winston. 1971.

Paivio, A., \& Smythe, P. C. Word imagery, frequency, and meaningfulness in short-term memory. Psychonomic Science, 1971, 22, 333-335.

Paivio, A., Yuille, J. C.. \& Madican, S. A. Concreteness. imagery, and meaningfulness values for 925 nouns. Journal of Experimental Psychology Monograph, 1968, 76(1. Part 2).

Paivio, A.. Yuille. J. C.. \& Rogers, T. B. Noun imagery and meaningfulness in free and serial recall. Journal of Experimental Psychology. 1969, 79. 509-514.

Postman, L. Verbal learning and memory. Annual Review of Psychology, 1975, 26. 291-335. 
Richardson, J. T. E. Imagery, concreteness, and lexical complexity. Quarterly Journal of Experimental Psychology, 1975, 27, 211-223. (a)

Richardson. J. T. E. Concreteness and imageability. Quarterly Journal of Experimental Psychology, 1975, 27, 235-249. (b)

Thorndike, E. L., \& LoRge, I. The teacher's word book of 30,000 words. New York: Columbia University, 1944.

WARREN, M. W. The effects of recall-concurrent visual-motor distraction on picture and word recall. Memory \& Cognition, 1977, 5, 362-370.
WINER, B. J. Statistical principles in experimental design. New York: McGraw-Hill, 1971.

Winnick, W. A., \& Kressel, K. Tachistoscopic recognition thresholds, paired-associate learning and free recall as a function of abstractness-concreteness and word frequency. Journal of Experimental Psychology, 1965, 70, 163-168.

(Received for publication January 15, 1978; revision accepted June 1,1978 .) 